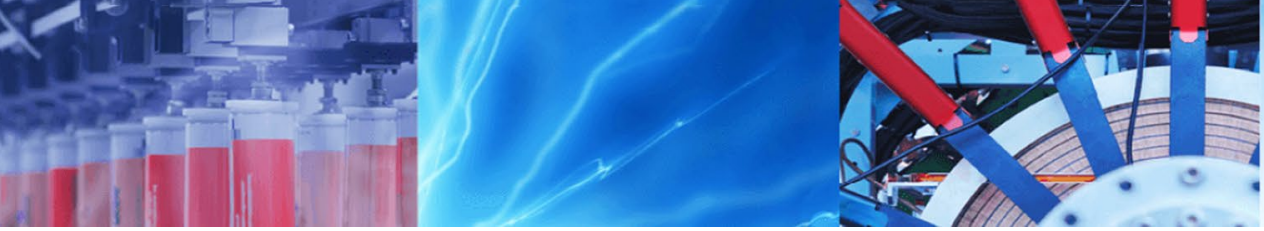

Research Article

\title{
The manufacturing technology of iron swords from the capital of the Han Empire in China
}

\author{
Fengyan Zhao ${ }^{1,2} \mathbb{D} \cdot$ Manli Sun $^{1} \cdot$ Xiuhui $\mathrm{Li}^{3} \cdot \mathrm{Fei} \mathrm{Guo}^{2} \cdot{\text { Mengyu } \mathrm{Li}^{3}}^{3}$
}

Received: 28 February 2020 / Accepted: 7 August 2020 / Published online: 13 August 2020

(c) Springer Nature Switzerland AG 2020

\begin{abstract}
Xi'an City was the capital of China during the Western Han (202 BC-8 AD) and Xinmang (8-23 AD) periods. Metallographic studies of iron swords from this region are very rare. This study analyzed six iron swords from different tombs in Xi'an by metallographic examination, scanning electron microscopy, and energy-dispersive spectrometry. These results indicate that one sample was produced using a direct smelting process, while the other samples were made from Chaogang (炒钢) decarburization of indirect process. Two swords were identified as very early Bailiangang (百炼钢) objects, which were highly valued at that time. This study supplements current analytical data on the center of the Han Empire.
\end{abstract}

Keywords Han dynasty · Iron sword · Metallography · SEM-EDS · Manufacturing techniques · Chaogang · Bailiangang

\section{Introduction}

The history of the sword is the history of humanity [1]. It begins in the prehistoric period, when stone axes were created, and then, hilts were added. During the third millennium BC, copper and bronze materials were used for blade manufacture; in the second millennium $B C$, daggers were transformed into swords in most parts of the world; by $900 \mathrm{BC}$, iron and some techniques (hammering, folding and welding, etc.) were used to produce stronger, more flexible, more long-lasting, and more lethal swords [2]. In China, the earliest smelted iron sword was made in Henan Province during the late Western Zhou dynasty (1046-771 BC) [3]. Currently, there are no more than two dozen extant swords manufactured before the seventh century $B C$ [4]. During the Han dynasty (202 BC-220 AD), iron production was greatly developed $[5,6]$. As a result, a large number of iron swords were manufactured all over the country and came to replace bronze swords. We analyzed the statistics of 220 intact Han tombs in Xi'an, Shaanxi Province [7-9]. Our analysis showed that about $35 \%$ of the tombs included burial of weapons: the bronze weapons were mainly crossbows, while the iron weapons consisted of swords and knives. The ancient Chinese book Jin Shu (The book of Jin dynasty, 晋书) recorded that “Han's rule requires officials, including the emperor, to carry swords." It is thus evident that swords occupied a significant position in Han society. The sword served not only as a weapon but also as a symbol of social standing, a fashion accessory, a talismanic object, or a recreational tool [4, 10-12]. Based on their general characteristics, these swords can be grouped into three categories-long $(>70 \mathrm{~cm})$, medium $(30-70 \mathrm{~cm})$, and short $(30 \mathrm{~cm})$, with different subtypes in each category [4-10] (Fig. 1a-e). In general, very few Han swords were short swords. They were instead primarily long swords and medium swords, and mainly of the types

\footnotetext{
Electronic supplementary material The online version of this article (https://doi.org/10.1007/s42452-020-03312-x) contains supplementary material, which is available to authorized users.
}

Fengyan Zhao, fyzhao717@163.com | 'School of Cultural Heritage, Northwest University, Xi'an 710069, China. ${ }^{2}$ Xi'an Institute of Conservation and Archaeology, Xi'an 71068, China. ${ }^{3}$ Institute of Cultural Heritage and History of Science and Technology, University of Science and Technology Beijing, Beijing 100083, China. 
Fig. 1 Types and components of iron swords (a-e different types; $\mathbf{f}$ the name of each part; g jade items on bronze sword [14]; $\mathbf{h}$ jade items on iron sword [15])
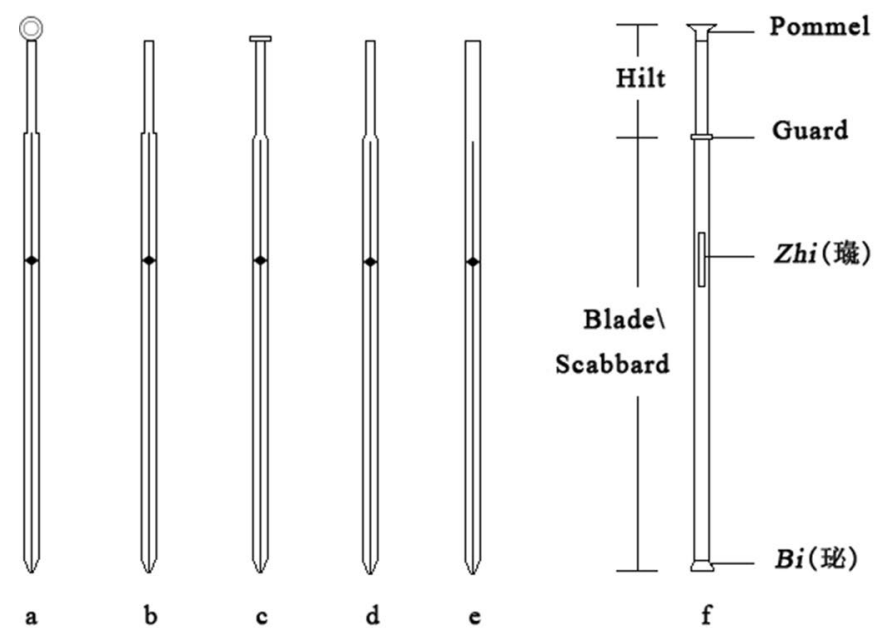

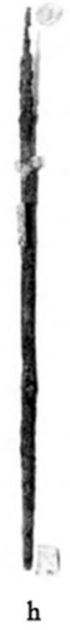

illustrated in Fig. 1b, d, in which the connection between hilt and blade is either square (Fangjian, 方肩) or oblique (Xiejian, 斜肩). The blades are straight, double edged, and slender, with a width of no more than $4 \mathrm{~cm}$. Although the swords vary in appearance, their structure is roughly consistent, normally including a pommel (Shou, 首), guard ( $G e$, 格), and scabbard ornamentations known as Zhi (㻼) and $B i$ (珌) $[4,10,13]$ (Fig. 1f). In some cases, jade was used to make these parts, a sign of the highest luxury manufacture and marking its owner as a noble. These jade items can similarly be found on bronze swords (Fig. 1g) [14], as well as on iron swords, although the iron parts are by now severely rusted (Fig. 1h) [15].

The technique of malleable soft iron manufacture in ancient China is thought to have included the steps illustrated in Fig. 2. There are two pathways for soft iron making $[16,17]$. One pathway is the direct process in which bloomery iron is smelted in a bloomery furnace. The bloomery iron, with a low-carbon content in the range of $0.1-0.3 \%$, can then be directly used for smithing. The second, indirect process is more complex. After smelting from a blast furnace, cast iron is decarburized through either a liquid-state process (Chaogang -炒钢) or a solid-state

process (annealing). This produces malleable soft iron as either wrought iron or steel (carbon content of $0.3-1 \%$ ). The first of these decarburization processes, Chaogang, is a fining technique that consists of re-melting cast iron in a hearth or open fire; it may have been employed for soft iron production since the late Warring States period, around the third century BC [18].

Iron sword technology is the epitome of the iron industry. Previous studies conducted microstructural and compositional analysis on a small amount of Han swords unearthed from kings' tombs, non-kings' tombs, and construction sites [19-24]. The swords were identified as bloomery iron, cast iron with solid-state decarburization, and Chaogang iron. In Shaanxi Province, three Han swords from Fufeng and Taicheng, in the surrounding area of Xi'an City, have been subjected to such examination $[25,26]$. In contrast, the metallurgical technology of Han swords in Xi'an has not attracted much research interest to date. Xi'an (historically named Chang'an) was the capital of China during the Western Han (202 BC-8 AD) and Xinmang (8-23 AD) periods. Therefore, the study of the techniques used for local manufacture of iron swords is essential to better

Fig. 2 Manufacturing pathway to soft iron through direct and indirect process in early ancient China

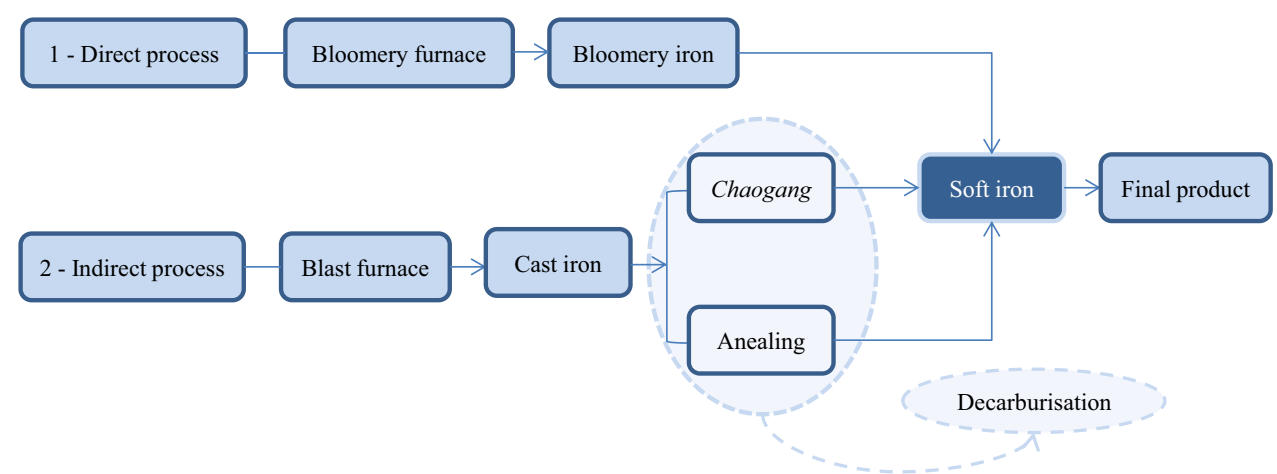


understand iron production in the whole society of this period. It is important to supplement the analytic data which are currently known for this region. Such research could also identify whether the capital used a special iron technique.

This study investigated iron swords excavated from Han tombs in Xi'an City. To develop an understanding of the iron-making technique used to produce them, the metallographic structure of samples was analyzed and samples were subjected to slag inclusion (SI) elemental analysis.

\section{Artifacts}

Table 1 provides summary information for the six iron swords studied in this paper. These swords were recovered from six tombs in Xi'an, China, dating from the early Western Han to Xinmang periods. These tombs are located in an area, presumed to be a citizens' cemetery, near the eastern wall of Chang'an City-the capital of the Western Han and Xinmang dynasties [8] (Fig. 3). Objects from these tombs could help us further understand the citizens' social life. Among these tombs, 98JX M204, FXC M12, YHHY M57, and YHHY M94 were robbed, whereas XBYL M1 and JXHY $M 80$ were well preserved and contained several artifacts.

Table 1 Brief information on the iron swords

\begin{tabular}{|c|c|c|c|}
\hline No. & Tomb & Appearance & Period \\
\hline TJ007 & 98JX M204 & $43.5 \mathrm{~cm}$ long and $3 \mathrm{~cm}$ wide. Wooden remnant on the sword's blade & Early Western Han \\
\hline TJ021 & FXC M12 & $\begin{array}{l}49 \mathrm{~cm} \text { long and } 3.2 \mathrm{~cm} \text { wide. Rhombic stone guard. Wooden remains visible on the } \\
\text { sword's blade }\end{array}$ & Middle Western Han \\
\hline TJ019 & YHHY M57 & $\begin{array}{l}90.5 \mathrm{~cm} \text { long and } 3 \mathrm{~cm} \text { wide. Double edges and rhombic stone guard. Golden and } \\
\text { wooden remnants can be seen }\end{array}$ & Middle and Late Western Han \\
\hline TJ001 & XBYL M1 & $\begin{array}{l}12 \mathrm{~cm} \text { long and } 3 \mathrm{~cm} \text { wide. Rhombic copper guard. Wooden remains on the sword's } \\
\text { blade and hilt }\end{array}$ & Late Western Han \\
\hline TJ004 & JXHY M80 & $93 \mathrm{~cm}$ long and $3.5 \mathrm{~cm}$ wide. Double edged blade with wooden remnant & Xinmang \\
\hline TJ020 & YHHY M94 & $\begin{array}{l}13.2 \mathrm{~cm} \text { long and } 3.5 \mathrm{~cm} \text { wide. Rhombic copper guard. Wooden remnant on the sword's } \\
\text { blade and hilt }\end{array}$ & Xinmang \\
\hline
\end{tabular}

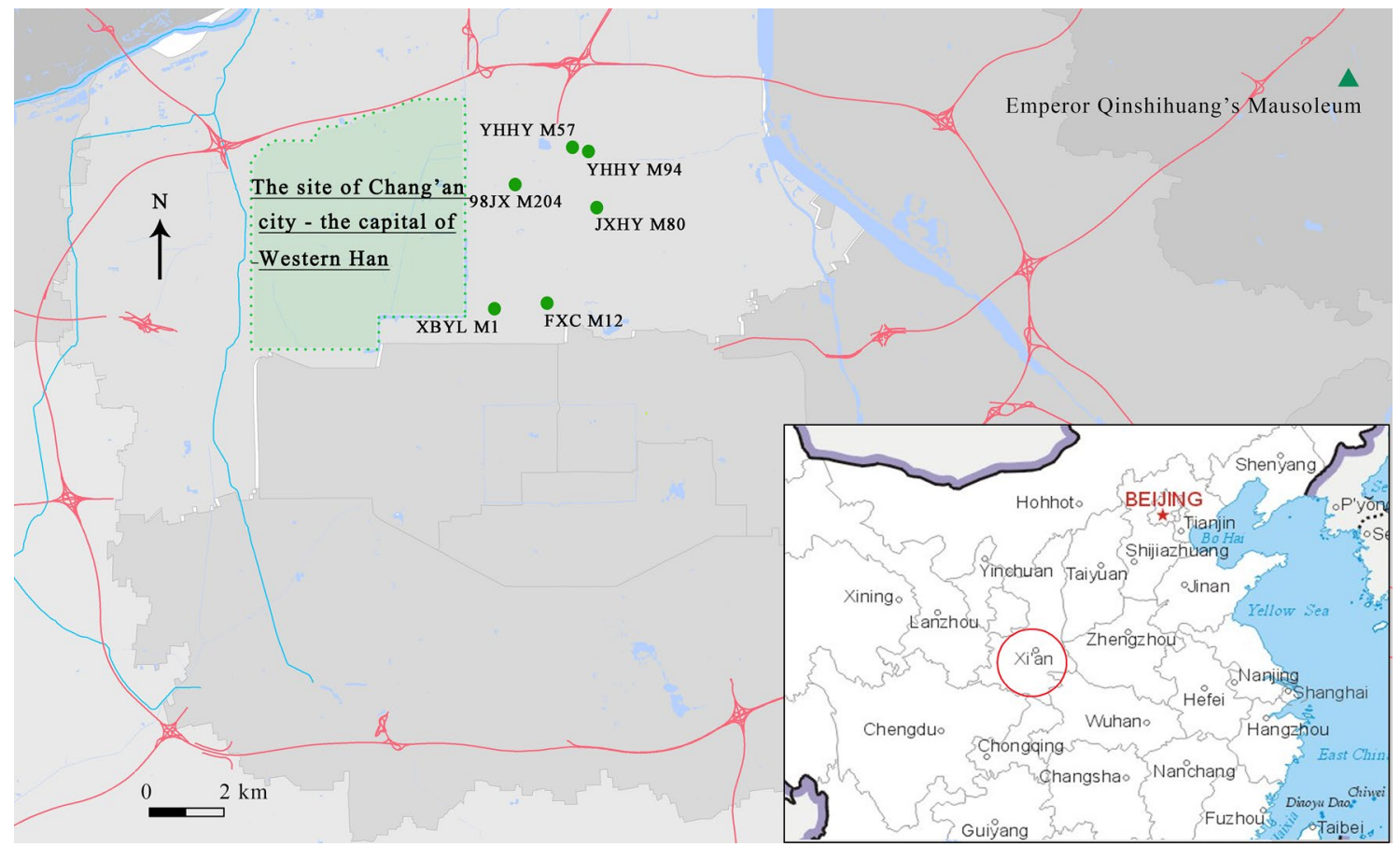

Fig. 3 Location of the six tombs in Xi'an, China 
TJ001 was excavated from XBYL M1 in 1988, along with human bones, 17 copper coins, and 41 other relics including an iron knife, two iron pots, a jade $Z$ hi from the iron sword TJ001, two bronze mirrors, two lead ornaments, ten bronze ornaments used on horse-drawn carriages, and 23 earthenware items. The stylistic characteristics of the Zhaoming (昭明) mirrors, Wuzhu (五铢) coins, and glazed earthenware objects placed the chronology of this grave in the late Western Han (48 BC-8 AD). TJ004 was excavated from JXHY M80 in 2002 together with two human skeletons, 279 copper coins, and 76 other artifacts including two bronze mirrors, a bronze belt hook, two bronze pots, an ink stone, two stone rhinobyons, two stone butt plugs, 12 bony ornaments, 37 shells, and 17 ceramic items. This tomb was dated to the Xinmang period according to the characteristics of the recovered mirrors, glazed ceramic artifacts, and coins (including different inscriptions of Daquanwushi一大泉五十，Xiaoquanzhiyi一小泉直一， Dabuhuangqian一大布黄千, Youbusanbai一幼布三百, and Yaobuerbai一幺布二百). TJ007 was excavated from 98JX M204 in 1998, along with human bones and 15 artifacts including an iron knife, a bronze belt hook, copper coins, six jade fragments, and seven ceramic objects. This grave was dated to the early Western Han (202-141 BC) based on the coin's inscription Banliang (牛两) and the characters on the bronze belt hook and ceramic objects. TJ019 was unearthed from YHHY M57 in 2000 together with an ink stone and ten ceramic vessels. This grave was dated from the middle Western Han to the late Western Han (140-8 AD) according to features of the ceramic artifacts. TJ020 was excavated from YHHY M94 in 2000, along with human bones, 15 copper coins, and 25 other items including two iron knives, an iron pot, a bronze mirror, two jade pieces in the mouth, two jade rhinobyons, two jade ear plugs, two glass ear ornaments (Erdang一耳珰), a jade disk, an ink stone, and 11 earthenware objects. The chronology of this tomb was placed in the Xinmang period based on the Riguang (日光) mirror, Wuzhu coins, Huoquan (货泉) coins, and glazed ceramic objects. TJ021 was recovered from FXC M12. This site was excavated in 1997, and yielded remains of an iron knife, copper coins (with Wuzhu inscription,) and a ceramic pot from the middle Western Han. The swords were laid near the bones in the wooden coffins (of which only remnants were left), likely implying that the swords were important belongings in daily life. Moreover, the swords were recovered together with knives from four of the tombs (98JX M204, YHHY M94, FXC M12, and XBYL $M 1)$. This likely reflects a reduction in the weapon function and a strengthening of the social standing significance of sword use in this period. Meanwhile, the knife was increasingly regarded as the main weapon after that time.

The appearances of the swords are illustrated in Fig. 4. All swords were found non-integrated. The longest

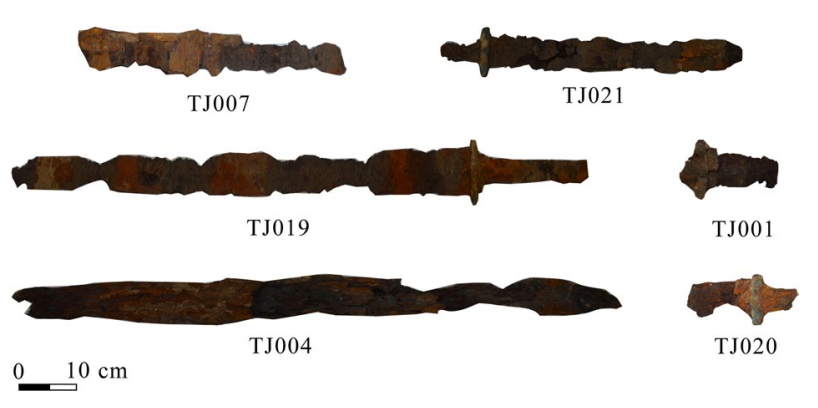

Fig. 4 Iron sword fragments with remnants of scabbard

fragment has a length of $93 \mathrm{~cm}$, and the shortest one is $12 \mathrm{~cm}$ long. The widths are in the range of $3-3.5 \mathrm{~cm}$. Four fragments have guards, which are rhombic and consist of either jade or copper. The surfaces of the blades have attached wooden remnants. Golden remnants can be seen at the connection between the guard and hilt of fragment TJ019. The original swords in that time would have been well decorated and carefully wrapped in scabbards made of wood, textile, paper, and other organic materials [27]. However, they were all found severely corroded upon excavation. Consequently, these iron swords present a wide range of damage such as fracture, incompleteness, crack, and thick layers of corrosion. Samples were taken from the places where the sword's blade was fractured, showing the iron core.

\section{Methods and results}

\subsection{Methods}

Metallography is an important tool to obtain information on an object's manufacturing process, thermal history, and corrosion products [28]. In this way, the phases (ferrite, pearlite, widmannstätten, etc.), approximate carbon content, and slag inclusions (SI) can be investigated. Then, the preliminary judgment regarding the type of iron and techniques of manufacture can be made. For this reason, metallography was chosen as the first step for this analysis. Samples were embedded in bakelite blocks, polished, and etched by a solution of $4 \mathrm{wt} \%$ nitric acid in ethanol. A Leica DM4000 metalloscope was then used to investigate the metallographic structure and SIs of the samples at the cross section.

Combining metallography with SEM-EDS is a conventional method of analysis in archaeometallurgy research. Together, these techniques can provide satisfactory evidence for the judgment of materials and techniques. Samples were polished again and coated with carbon after metallographic examination. Scanning electron microscopy (SEM) was then used to investigate the SI's 
micro-scale morphology. The most prevalent elements in the SI were measured by energy-dispersive spectrometry (EDS). For SEM, a ZEISS EV018 high-resolution scanning electron microscope was used. The BRUKER X Flash Detector 5010 was used for EDS. The accelerating voltage was $20 \mathrm{kV}$, with a working distance of $15 \mathrm{~mm}$ and a counting time of $60 \mathrm{~s}$.

\subsection{Results}

In the metallographic investigation, ferrite and pearlite were observed in all samples in different quantities; this result is indicative of differences in carbon content. Ferrite indicates lower carbon content, as compared to the higher carbon content of pearlite. The structure of TJ007 is even and consists of fine pearlite and ferrite, suggesting that it is mid-carbon steel with a carbon content of approximately $0.3-0.5$ wt\% (Fig. 5a). TJ021, TJ001, and TJ004 all have a similar carbon concentration. The microstructure of TJ019 shows the features of eutectoid steel, with a carbon content of 0.5-0.7 wt\%. In TJ020, abundant ferrite was present with a grain size grade of $5-6$, indicative of wrought iron, with a carbon concentration of $0.1-0.3 w t \%$. Four samples presented structures with multiple layers of different carbon contents, indicating that folding had been used during smithing. TJ021 consists of 11 layers divided into two types of structures with different carbon contents. One type is dominated by fine pearlite and ferrite, while the other consists of coarse pearlite and ferrite and forms five layers of high carbon belts (Fig. 5c). The structure of TJ001 is divided into 30 layers. Both sides of each layer symmetrically bend toward the center (Fig. 5f). The carbon content is low in the middle and high on both sides. The stratification of TJ004 is obvious and can be divided into about 37 layers of approximately equal thickness (Fig. 5d). TJ020 consists of 10 layers with ferrite and very small amounts of pearlite (Fig. 5e). A small widmannstätten structure can be seen at the edge of TJ019 (Fig. 5b), indicating the use of a carburizing process.

The quantity, distribution, morphology, and composition of SIs all relate to the iron-making process. For TJ020, the amount of SIs distributed in the layers with high carbon content is greater than that in the layers with low-carbon content. The SIs are composed of long, large particles, showing large-scale deformation that suggests TJ020 was hammered. SIs in the other five samples also show this characteristic deformation.

The backscattered electron images of SIs present their morphology in micro-scale. Four types of SIs can be highlighted in this fashion. The first has the feature of glassy $\mathrm{SiO}_{2} \mathrm{Sl}$, with high silicon and calcium and low-iron content (Fig. 6b; Table 2). The second has a small amount of iron oxide on a glassy matrix, with high silicon and moderate iron content (Fig. 6f; Table 2). The third type is fayalitic (Fig. 6c; Table 2). The fourth shows wüstite in a fayalitic matrix, with high iron content (Fig. 6a, d, e; Table 2). High Ca-P phases were found near the wüstitefayalitic phase in TJ020, TJ001, and TJ021 (Fig. 7). The EDS results for the SIs indicate their relative homogeneousness in TJ007 and variable chemical composition in the other five samples (see supplementary material.)
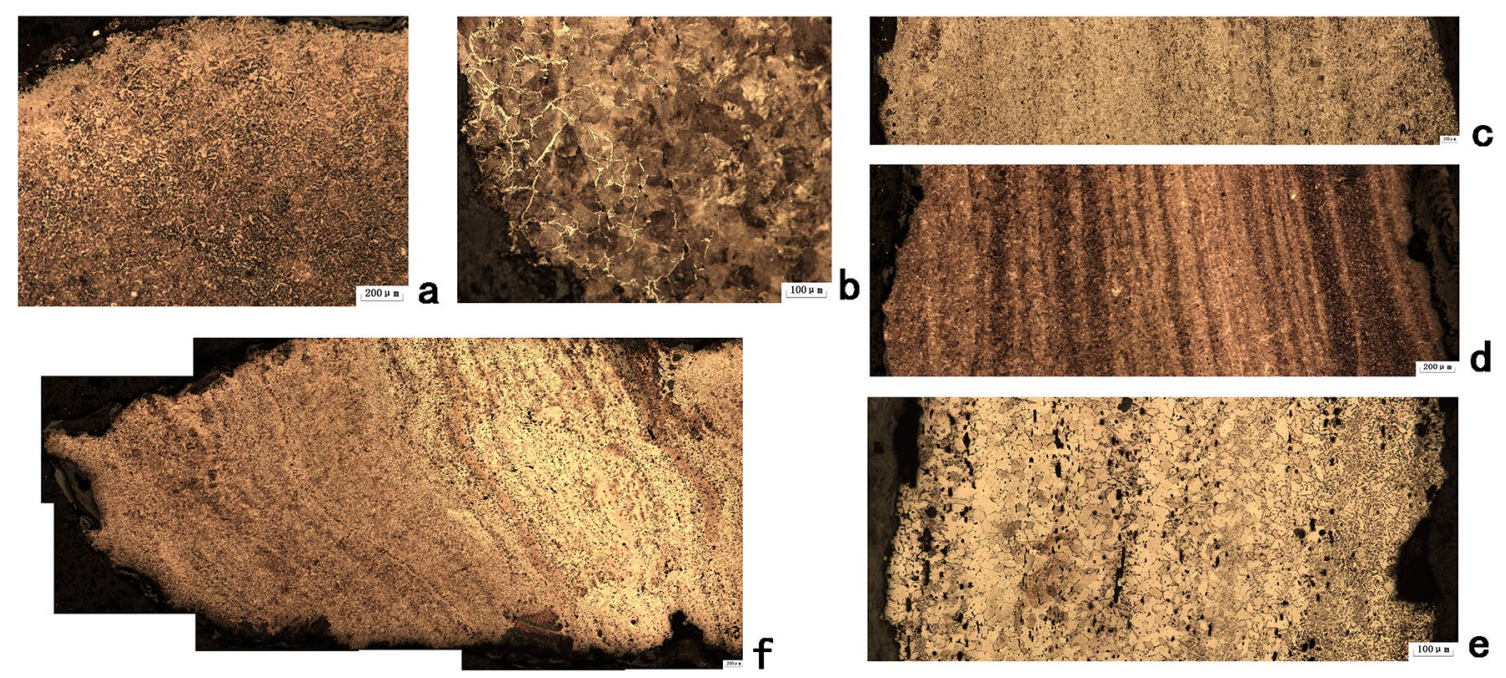

Fig. 5 Metallographic structure of samples (a TJ007; b TJ019; c TJ021; d TJ004; e TJ020; f TJ001) 

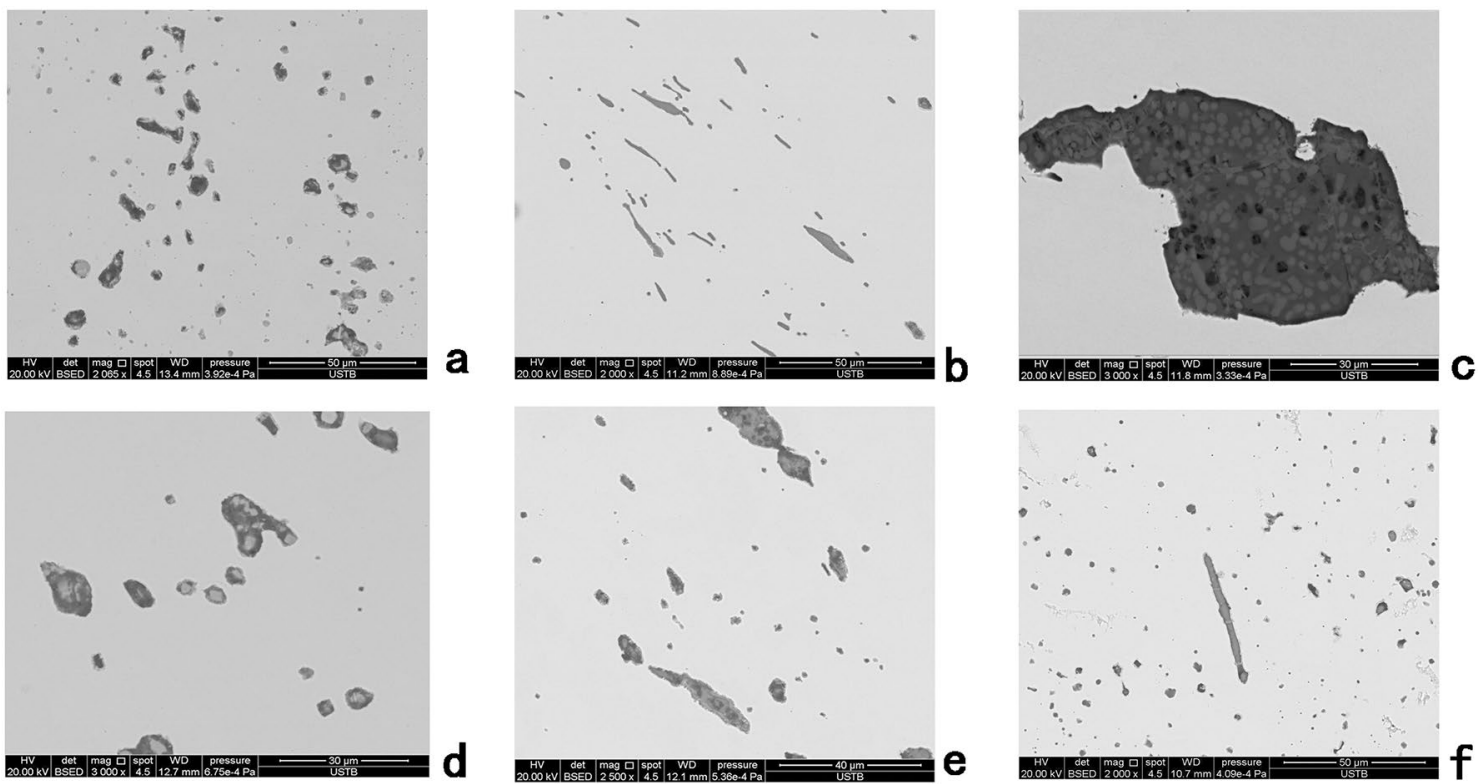

Fig. 6 Backscattered electron images of SIs (a TJ007; b TJ021; c TJ019; d TJ001; e TJ004; f TJ020)

Table 2 EDS results of representative SIs

\begin{tabular}{|c|c|c|c|c|c|c|c|c|c|c|c|c|}
\hline \multirow[t]{2}{*}{ Sample } & \multirow[t]{2}{*}{ Feature } & \multicolumn{10}{|c|}{ Element content (wt\%) } & \multirow[t]{2}{*}{ Image } \\
\hline & & $\mathrm{O}$ & $\mathrm{Na}$ & $\mathrm{Mg}$ & Al & $\mathrm{Si}$ & $P$ & K & $\mathrm{Ca}$ & $\mathrm{Mn}$ & $\mathrm{Fe}$ & \\
\hline \multirow[t]{3}{*}{ TJ007 } & $W+F$ & 18.15 & 0.00 & 0.00 & 0.00 & 3.65 & 16.53 & 0.00 & 0.00 & 0.00 & 61.67 & \multirow[t]{3}{*}{ Figure 6a } \\
\hline & & 15.21 & 0.00 & 0.00 & 0.00 & 8.43 & 2.01 & 0.00 & 0.10 & 2.05 & 72.20 & \\
\hline & I & 22.84 & 0.00 & 0.00 & 0.00 & 0.36 & 0.36 & 0.00 & 0.55 & 0.00 & 75.90 & \\
\hline \multirow[t]{3}{*}{ TJ021 } & G & 24.42 & 0.10 & 2.19 & 5.99 & 31.10 & 0.10 & 2.84 & 23.58 & 1.16 & 7.91 & \multirow[t]{5}{*}{ Figure $6 b$} \\
\hline & $\mathrm{G}+\mathrm{I}$ & 32.18 & 0.42 & 1.02 & 2.26 & 10.67 & 1.02 & 0.79 & 8.22 & 0.77 & 42.65 & \\
\hline & $W+F$ & 32.59 & 0.00 & 0.76 & 0.33 & 5.39 & 8.04 & 1.76 & 2.26 & 0.00 & 48.86 & \\
\hline \multirow[t]{4}{*}{ TJ019 } & G & 41.57 & 0.85 & 1.82 & 4.82 & 21.93 & 0.00 & 2.16 & 22.19 & 0.00 & 4.23 & \\
\hline & $G+I$ & 11.36 & 0.10 & 1.51 & 6.11 & 40.39 & 0.10 & 2.82 & 15.34 & 0.10 & 22.17 & \\
\hline & $\mathrm{F}$ & 43.81 & 1.35 & 1.91 & 6.89 & 24.93 & 0.00 & 3.19 & 15.74 & 0.00 & 2.19 & \multirow[t]{4}{*}{ Figure $6 c$} \\
\hline & $W+F$ & 26.62 & 0.00 & 0.00 & 1.15 & 4.26 & 0.90 & 0.46 & 3.66 & 0.00 & 62.97 & \\
\hline \multirow[t]{3}{*}{ TJ001 } & G & 43.27 & 1.12 & 1.51 & 5.01 & 25.31 & 0.00 & 2.54 & 16.03 & 0.43 & 4.28 & \\
\hline & $G+I$ & 30.80 & 0.00 & 1.14 & 0.00 & 9.25 & 2.57 & 0.41 & 0.95 & 1.09 & 53.80 & \\
\hline & $W+F$ & 28.21 & 0.00 & 0.00 & 0.00 & 3.05 & 4.54 & 0.00 & 4.32 & 0.76 & 59.13 & \multirow[t]{3}{*}{ Figure $6 \mathrm{~d}$} \\
\hline \multirow[t]{3}{*}{ TJ004 } & G & 37.03 & 0.53 & 1.83 & 2.37 & 17.22 & 0.00 & 0.62 & 19.58 & 0.00 & 20.80 & \\
\hline & $\mathrm{F}$ & 37.25 & 1.06 & 2.06 & 3.79 & 17.26 & 0.00 & 3.01 & 17.62 & 0.00 & 16.37 & \\
\hline & $W+F$ & 15.20 & 0.10 & 3.35 & 5.83 & 14.38 & 0.10 & 1.08 & 16.04 & 0.10 & 43.82 & \multirow[t]{3}{*}{ Figure $6 \mathrm{e}$} \\
\hline \multirow[t]{4}{*}{ TJ020 } & G & 38.24 & 0.00 & 1.32 & 1.61 & 18.92 & 1.00 & 0.60 & 15.89 & 3.39 & 18.54 & \\
\hline & $\mathrm{G}+\mathrm{I}$ & 39.63 & 0.46 & 0.47 & 1.37 & 10.81 & 10.31 & 1.56 & 16.45 & 0.53 & 18.41 & \\
\hline & $\mathrm{F}$ & 37.24 & 0.00 & 3.93 & 0.00 & 4.13 & 13.36 & 0.56 & 7.89 & 1.44 & 31.45 & \multirow[t]{2}{*}{ Figure $6 f$} \\
\hline & $W+F$ & 31.16 & 0.00 & 0.00 & 0.00 & 9.50 & 3.25 & 0.00 & 0.59 & 1.62 & 53.89 & \\
\hline
\end{tabular}

$W$ wüstite, $F$ fayalite, $G$ glassy matrix, I iron oxide 


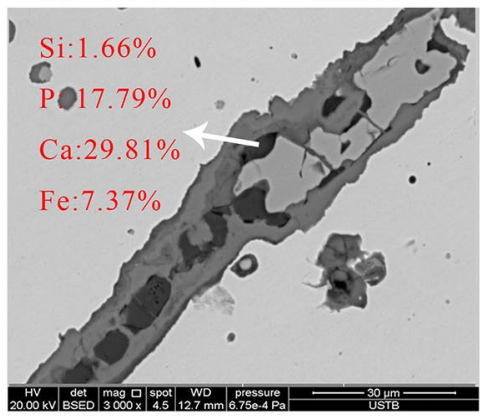

a

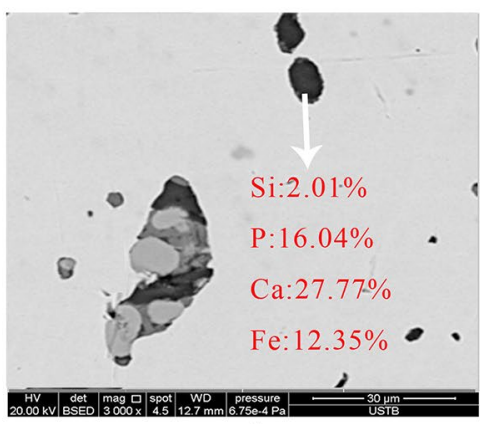

b

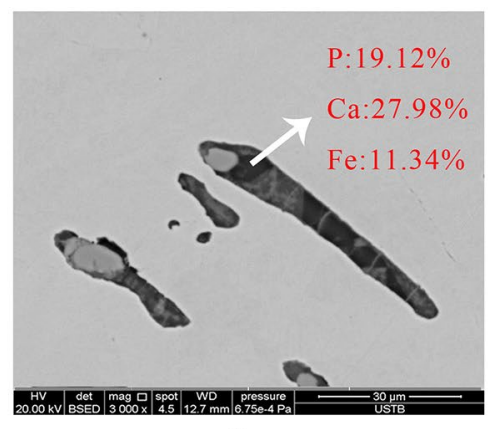

C

Fig. 7 Ca-P phases in SIs (a TJ020; b TJ001; c TJ021)

\section{Discussion}

\subsection{Iron manufacturing process}

Slag inclusions ( $\mathrm{SI}$ ), with different morphologies and chemical compositions, are the most important diagnostic factor for discerning the manufacturing process used to create a soft iron product. If an iron object is made via a direct system, it will contain Sls characterized by abundant particles, largely multi-phase in composition, and with high concentrations of iron [29-32]. When the iron is further subjected to a smithing process, new SIs may be formed, while the original SIs may be altered $[33,34]$. When a cast iron process is used, the smelting slag has a much lower-iron content, especially when a calcium-rich flux is used [26, 35]. Hence, the use of such flux will create SIs with a higher concentration of calcium than is found in the Sls produced by a direct process. In addition, the $\mathrm{P}_{2} \mathrm{O}_{5}$ content of bloomery slag is generally higher than of blast furnace slag $[33,36]$. However, when the cast iron is decarburized in a liquid state (fining), the $\mathrm{P}_{2} \mathrm{O}_{5}$ content in its Sls will be higher than in Sls from a direct process and solid-state decarburization (annealing) $[26,33,35]$. In summary, this means that iron, calcium, and phosphorus in SIs are the three most essential indicators for differentiating between the direct and indirect processes, as well as between liquid-state and solid-state decarburization.

To apply these criteria, the ratios of $\mathrm{Fe} / \mathrm{Ca}$ and $\mathrm{Fe} / \mathrm{P}$ were calculated and are plotted as shown in Fig. 8. Measurements taken from TJ007 appear as a cluster on the plot, with a higher-iron and lower-calcium content than other samples. By contrast, the phosphorus content of SIs from TJ007 was significantly inhomogeneous, with a higher concentration in some SIs than others. These data suggest that TJ007 was likely made using the direct process.

The data indicate that the other five swords were made through the indirect process. In these swords, the calcium concentration in the SIs is often high and variable (Table 2 and supplementary); this condition is rarely seen in SIs from objects produced using the direct process. Given that the ratio of non-reduced compounds (NRC) in Sls from the same process should remain constantly and comparably [33], the $\mathrm{MgO} / \mathrm{Al}_{2} \mathrm{O}_{3}, \mathrm{Al}_{2} \mathrm{O}_{3} / \mathrm{SiO}_{2}, \mathrm{~K}_{2} \mathrm{O} / \mathrm{CaO}$, and $\mathrm{MgO} / \mathrm{SiO}_{2}$ weight percentage ratios were calculated; variations in these ratios and overall trends of grouping are shown in Fig. 9. These results indicate that the ratios in TJ021, TJ004, and TJ020 are more concentrated in one group which is
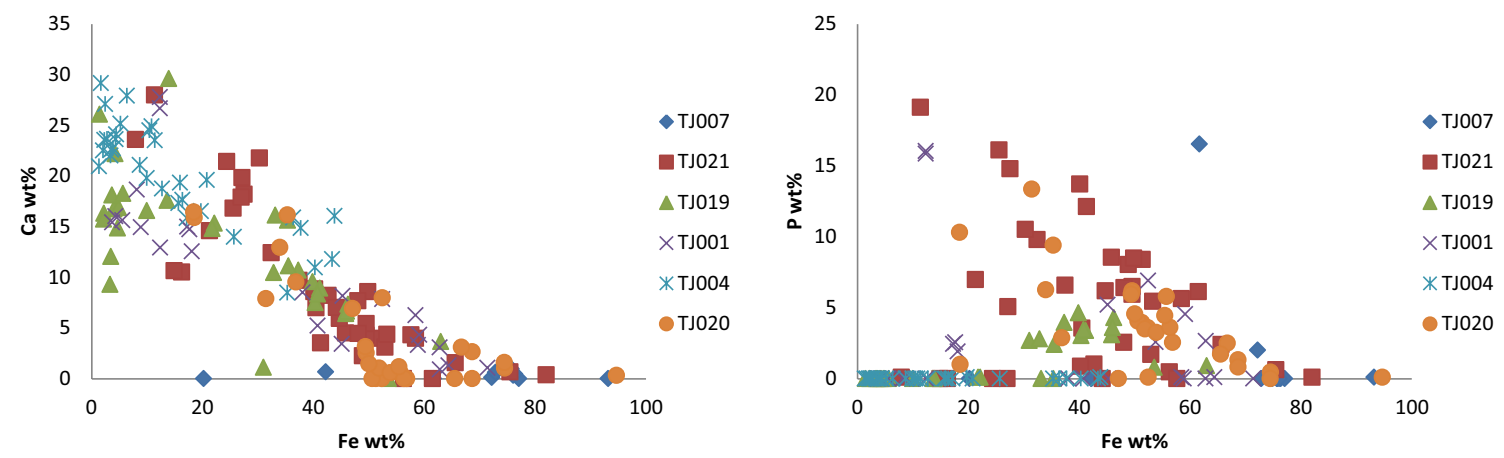

Fig. 8 Bivariate plots of $\mathrm{Fe} / \mathrm{Ca}$ and $\mathrm{Fe} / \mathrm{P}$ in Sls of samples 

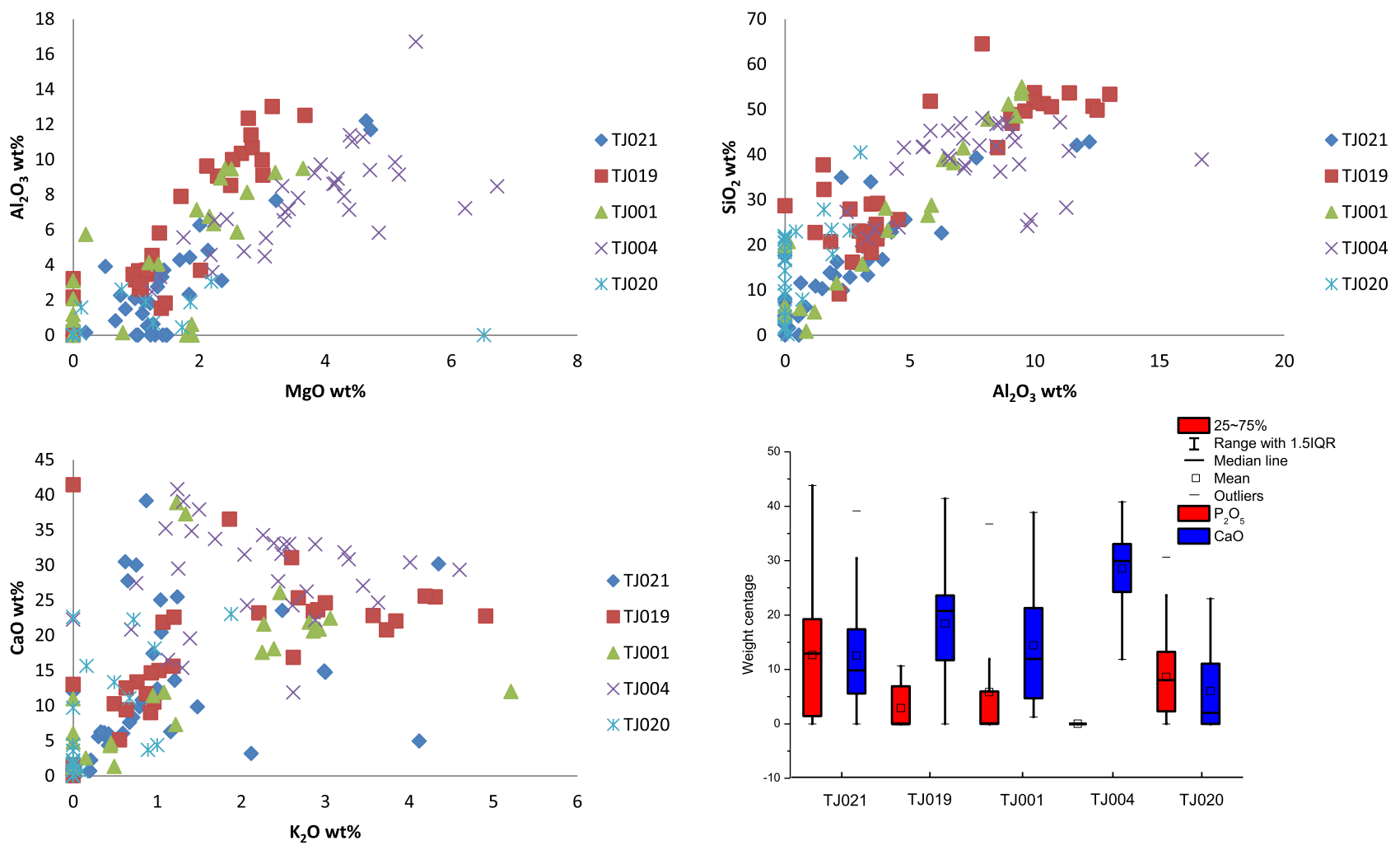

Fig. 9 Bivariate plots of non-reduced compounds (NRC) in SIs for samples TJ021, TJ019, TJ001, TJ004 and TJ020, and box-whisker plot of $\mathrm{P}_{2} \mathrm{O}_{5}$ and $\mathrm{CaO}$ concentrations in Sls

closely related to fining stage. By contrast, there is a trend of two subgroups for the ratios in TJ019 and TJ001, which is more likely to be indicative of the use of fining and smithing processes. The high concentrations of $\mathrm{P}_{2} \mathrm{O}_{5}$ and $\mathrm{CaO}$ in SIs from these swords are further indicative of fining products (Fig. 9). The concentration of phosphorus in TJ004 is so low as to be undetectable. This may be because the original cast iron used for decarburization contained very little phosphorus.

\subsection{Swords' materials}

TJ007 is dated from the early West Han dynasty and made of bloomery iron. The swords from the Mancheng Han tombs in Hebei Province, which date from the same period, were also found to be produced from bloomery iron [20]. In this period, the Chaogang process was widely used for weapons and tools, including the iron sword from the Nanyue King tomb in Guangdong Province [19], the iron sword unearthed from the Chengcunhancheng site in Fujian Province [22], as well as the iron arrowhead and spear found in the Xushui Dongheishan site in Hebei [30]. This shows that iron swords in the early Western Han dynasty were made from both bloomery iron and using the Chaogang process.
Five of the samples analyzed in this study, originating from the middle Western Han dynasty to the Xinmang period, are here identified as Chaogang products. To compare this to other regions of the same period in China, the iron sword from the Shenmingpu site in Henan Province was made of cast iron with a solid-state decarburization process [21], two iron swords unearthed from the Lijiashan Han tomb in Yunnan Province were identified as being made from Chaogang product [23], the iron sword excavated from the Tianchang Han tomb in Anhui Province was cast iron produced with a solid-state decarburization process [24], and the iron sword from the Fufeng Han tomb in Shaanxi Province was made from Chaogang product [25]. This shows that from the middle of the Western Han dynasty to the Xinmang period, cast iron was widely used for the production of iron swords.

There were many reasons for the development of iron production to the highest level in the Han dynasty [4]. One essential reason was that the bronze industry had already reached a high level of technological development. The other important reason was the policy of Yantieguanying (盐铁官营), which mandated that iron production is controlled by the government, with the result that more human and financial resources were invested in it. This 
caused a subsequent increase in the scale and technological development of the iron industry.

\subsection{Bailiangang}

Samples TJ001 and TJ004 present a metallographic structure with more than 30 layers. This indicates these swords were produced using the Bailiangang (百炼钢, “hundredfold refining") technique. For these two swords, Chaogang products were used as raw material. Repeated heating, folding, and hammering steps produced a layered or laminated structure [17,37-39], as seen in the metallographic examination above. These steps were repeated several times, typically producing $16,32,64$, etc. layers $[17,39]$. Such processing significantly improved qualities such as strength and ductility $[17,37]$. The Bailiangang smithing process was an extreme example of this technique: the term Bai, meaning "hundred," refers to the approximate number of times the metal was folded. In general, iron folded more than 30 times can be identified as Bailiangang product. By contrast, swords TJ020 and TJ021 are laminated with approximately 10 layers, ruling out the possibility of Bailiangang. Similar laminations of iron objects were also found in other areas $[18,26,40]$.

These results from swords TJ001 and TJ004 indicate that the late Western Han and Xinman periods were the very early period for use of the Bailiangang technique. To date, all archaeological Bailiangang objects (as identified via metallographic analysis) have been swords and knives and mainly date from the Eastern Han dynasty. The most representative artifacts are the Sanshilian ("30-fold refining") knife of the Eastern Han dynasty (23-220 AD), unearthed from Cangshan, Shandong Province [41], and the Wushilian ("50-fold refining") sword of the Eastern Han dynasty from Xuzhou, Jiangsu Province [42]. The inscription Zhiqianwubai (直千五百) on the latter can be translated as "worth 1500 coins." According to the Han's literature of Juyanhanjian (居延汉简, Bamboo scripts of Han dynasty found in Juyan), the price of a sword of average quality was 650 coins [43]. This price was indeed quite high, equivalent to the price of more than $200 \mathrm{~kg}$ of grain during an ordinary year [44]. Thus, 1500 coins would have been sufficient to feed one man for more than two years [37]. It can be inferred that the TJ001 and TJ004 swords, being Bailiangang swords, might each cost about 1000 coins. This was approximately equivalent to the price of $300 \mathrm{~kg}$ of grain. Moreover, a number of other objects were also buried in the tombs of TJ001 (along with a jade Zhi) and TJ004. This indicates that the buried persons were noble or wealthy. Their status reflects the fact that the Bailiangang swords were expensive during the late Western Han and Xinmang periods.

\section{Conclusions}

This study conducted a metallographic investigation and slag inclusion analysis of six iron swords from the Han period discovered in tombs in Xi'an. TJ007 was identified as having been produced using a direct smelting process, while the other five samples were made using an indirect process, specifically a liquid-state decarburization technique.

Based on these results, together with other studies, it is concluded that from the middle of the Western Han dynasty, cast iron worked via a fining process was widely used for the production of iron swords. Among the investigated swords, TJ001 and TJ004 are two very early examples of Bailiangang artifacts, which carried a high price at that time. This is the first time iron swords excavated from Xi'an City, the center area of the Han Empire, have been subjected to scientific examination. Although this study has supplemented the available data for this area, the total amount of data is still small and more samples should be studied in the future in order to gain a fuller understanding of social life in the early iron age of China.

Acknowledgments The authors greatly appreciate the funding obtained from the Xi'an Institute of Conservation and Archaeology. We also thank Xiaojuan Huang, Jingyi Shen, Chen Wu, Rui Guo, and Jian Wang for their help with data collection and experimental analysis.

Funding The research was supported by the Xi'an Institute of Conservation and Archaeology, China.

\section{Compliance with ethical standards}

Conflict of interest The authors state that there is no conflict of interest.

\section{References}

1. Richard FB (1987) The book of the sword. Dover Publications, New York

2. McNab C (2010) Knife and swords-a visual history. DK Publishing, New York, pp 8-9

3. Han R (1998) An metallographic study on early iron objects of China (Zhongguo gudai zaoqi tieqi (gongyuanqian 5 shiji yiqian) de jinxiangxue yanjiu 中国早期铁器(公元前5世纪以 前)的金相学㸴究). Cult Relics 2:87-96

4. Bai Y (2005) Archaeological research on iron artefacts dating from pre-Qin and Han dynasties (Xianqin lianghan tieqi de kaoguxue yanjiu 先秦两汉铁器的考古学硎究). Science Press, Beijing, pp 285-287

5. Rubin H, Jun K (2007) History of science and technology in China volume of mining (Zhongguo kexuejishushi kuangyejuan 中国科学技术史·矿冶卷). Beijing: Science Press, pp 446 
6. Wagner DB (2008) Chemistry and chemical technology part 11: ferrous metallurgy. Joseph Needham. Science and civilisation in China. Cambridge, Cambridge University Press, pp 115-248

7. Xi'an Institute of Conservation and Archaeology (1999) Han tombs in Longshouyuan district of Xi'an city (Xi'an longshouyuan hanmu 西安龙首原汉墓). Northwest University Press, Xi'an, pp 256-261

8. Xi'an Institute of Conservation and Archaeology \& Archaeology Department of Zhengzhou University (2004) Chang'an Han tombs (Changan hanmu 长安汉墓). Xi'an: Shaanxi People's Press, pp 894-969

9. Xi'an Institute of Conservation and Archaeology (2008) Xi'an donghanmu 西安东汉墓. Cultural Relics Press, Beijing, pp 1044-1076

10. Zhong $S$ (1998) A comprehensive study of the Han style of iron sword (Hanshi tiejian zonglun 汉式铁剑综论). Acta Archaeologica Sinica 1:35-60

11. Jianying $H$ (2006) Chinese sword culture. China Today, pp 66-69

12. Pearce $M(2013)$ The spirit of the sword and spear. Cambridge Archaeol J 23:55-67

13. Sun J (2014) Materials cultural in ancient China (Zhongguo gudai wuzhi wenhua 中国古代物质文化). Zhonghua Book Company, Beijing, pp 213-367

14. Chongqing Municipal Cultural Heritage Research Institute, Fuling District Museum of Chongqing Municipality, and Chongqing Municipal Bureau of Cultural Heritage (2016) The Excavation of Tomb M12 of the Tombs at Xiaotian Creek, Fuling District, Chongqing Municipality (Chongqing Fuling Xiaotanxi muqun M12 fajue jianbao 重庆涪陵小田溪墓群M12发掘简报). Cultural Relics 9:4-27

15. Ruixue $L$ (2015) Study on ornaments of yujujian swords from Han dynasty (Handai yujujian jianshi jianxi 汉代玉具剑剑饰简析). J Chifeng Univ 36 (10): 30-32

16. Chen J, Han R (2000) Comparative studies on iron and steel artifacts unearthed from the tombs of Han princes (Han zhuhouwanglingmu chutu tieqi de bijiao 汉诸侯王陵墓出土铁器的比 较). Sci Conserv Archaeol 12(1):1-8

17. Wagner DB (1996) Iron and steel in ancient China. E. J. Brill, Leiden, pp 247-334

18. Liu Y, Martinón-Torres $M$, Chen J et al (2019) Iron decarburization techniques in the eastern Guanzhong Plain, China, during Late Warring States period: an investigation based on slag inclusion analyses. Archaeol Anthropol Sci. https://doi.org/10.1007/s1252 0-019-00921-5

19. Department of Metallurgy History, University of Science and Technology Beijing (2014) Examination report of iron objects unearthed from Nanyue King tomb of the West Han dynasty (Xihan nanyuewangmu chutu tieqi jianding baogao 西汉南越 王墓出土铁器鉴定报告). Metallurgy history papers written by Rubin Han. Beijing: Science Press, pp 222-233

20. Metallographic Laboratory (1986) Metallographic analysis report of some metal objects of Mancheng Han tomb (Mancheng hanmu bufen jinshuqi de jinxiangfenxi baogao 满城汉墓 部分金属器的金相分析报告). Symposium of Metallurgy History in China. Beijing: College of Iron and Steel Beijing, pp 120-125

21. Rong Y, Luo W, Wei G et al (2013) Study on manufacturing technique for iron artifacts unearthed from the Shenmingpu site (Shenmingpu yizhi chutu tieqi de gongyi kaocha 申明铺遗址出 土铁器的工艺考察). Sci Conserv Archaeol 25(3):64-70

22. Chen J, Yang C, Zhang H et al (2008) Metallographic research on iron objects unearthed from Chengcunhancheng site of Wuyishan in Fujian (Fujian Wuyishan Chengcunhancheng chutu tiegi de jinxiang shiyan yanjiu 福建武夷山城村汉城出土铁器的金相实 验㗏究). Cult Relics 3:88-96
23. Li X, Han R (2011) Study on metal technology of ancient Dian (Gudianguo jinshu jishu yanjiu 古滇国金属技术硎究). Science Press, Beijing, pp 93-99

24. Yan D, Qin Y, Chen Q et al (2011) Research on metal objects unearthed from Western Han dynasty tombs in Tianchang country (Tianchang xihanmu chutu bufen jinshuqi de yanjiu 天 长西汉墓出土部分金属器的㸴究). Nonferrous Metals 9:56-61

25. Dimin L (1999) Scientific analysis on steel sword of the Han dynasty in Fufeng (Fufeng handai gangjian de keji fenxi 扶风 汉代钢剑的科技分析). Archaeol Cult Relics 3:89-92

26. Lam W, Chen J, Chong J et al (2018) An iron production and exchange system at the center of the Western Han Empire: scientific study of iron products and manufacturing remains from the Taicheng site complex. J Archaeol Sci 100:88-101

27. Okada F, Ota A, Feng J et al. (2008) Study on sword and knife scabbard unearthed from Han tombs in Xi'an area (Xian diqu hanmu chutu jian-dao qiao de fenxi yanjiu 西安地区汉墓出土 剑(刀)鞘的分析研究). Eastern Han tombs in Xi'an. Beijing: Cultural Relics Press, pp 1089-1110

28. David AS (1991) Metallography and microstructure of ancient and historic metals. Singapore: The Getty Conservation Institute and J Paul Getty Museum, pp 57

29. Chen J, Ma Q (2010) Metallographic analysis and AMS $-{ }^{14} \mathrm{C}$ dating of some iron objects in Gansu area (Gansu diqu bufen tieqi de jinxiangzuzhi fenxi ji AMS $-{ }^{14} \mathrm{C}$ niandai ceding 甘肃地区部分 铁器的金相组织分析及AMS-14C年代测定). Key technology research of cultural heritage conservation. Beijing. Cultural Relics Press, Oxford, pp 65-80

30. Liu H, Chen J, Mei J et al (2013) Experimental study on iron objects unearthed from Dongheishan site of Xushui in Hebei (Hebei xushui dongheishan yizhi chutu tieqi de shiyan yanjiu 河 北徐水东黑山遗址出土铁器的实验砶究). Cult Relics Southern China 1:133-142

31. Yang J, Li Y, Zhao F et al (2014) Experimental studies on the iron objects unearthed from Mapaoquan site in Changping and a discussion of criteria for judging Chaogang (Beijing Changping Mapaoquan changcheng shusuo yizhi chutu tieqi de shiyan yanjiu-jianlun chaogang gongyi de yizhong panju 北京昌平马创泉长城戍所遗址出土铁器的实验㸴究——兼论 炒钢工艺的一种判据). Chin J His Sci Technol 35(2):177-187

32. Charlton MF, Crew P, Rehren T et al (2010) Explaining the evolution of ironmaking recipes-an example from northwest Wales. J Anthropol Archaeol 29:352-367

33. Dillmann P, L'Héritier M (2007) Slag inclusion analyses for studying ferrous alloys employed in French medieval buildings: supply of materials and diffusion of smelting processes. J Archaeol Sci 34(11):1810-1823

34. Blakelock E, Martinón-Torres M, Veldhuijzen HA et al (2009) Slage inclusions in iron objects and the quest for provenance: an experiment and a case study. J Archaeol Sci 36:1745-1757

35. Chen J, Zhang Z (2016) Identification of ancient Chaogang technology based on slag (Jiyu luzha fenxi de gudai chaogang jishu panding wenti 基于炉渣分析的古代炒钢技术判定问题). Cult Relics Southern China 1:115-121

36. Neff D, Dilmann P (2001) Phosphorus localization and quantification in archeological iron artefacts by micro-PIXE analyses. Nuclear Instrum Methods Phys Res B 181:675-680

37. Han R, Ke J (1984) Bailiangang in Ancient China (Zhongguo gudai de bailiangang 中国古代的百炼钢). Stud His Nat Sci 3(4):316-320

38. Wadsworth J, Lesuer DR (2000) Ancient and modern laminated composites-from the Great Pyramid of Gizeh to Y2K. Mater Charact 45:289-313

39. Wadsworth J (2015) Archeometallurgy related to swords. Mater Charact 99:1-7 
40. Park J-S, Gelegdorj E, Chimiddorj Y-E (2010) Technology traditions inferred from iron artefacts of the Xiongnu Empire in Mongolia. J Archaeol Sci 37:2689-2697

41. Liu X, Chen Z (1974) An iron knife of Yongchu Year of the Eastern Han found at Cangshan of Shandong (Shandong Cangshan faxian donghan yongchu jinian tiedao 山东苍山发现东汉永初纪年 铁刀). Cult Relics 12:61

42. Museum X (1979) A "fifty refining" steel sword of the $2^{\text {nd }}$ Jianchu of the Eastern Han found in Xuzhou (Xuzhou faxian donghan jianchu ernian wushilian gangjian 徐州发现东汉建初二年五十 涞钢剑). Cult Relics 7:51-52

43. Xie G, Li J (1987) Annotations emendation of the Juyan bamboo slips of the Han dynasty (Juyan hanjian shiwen hejiao 居延汉简 释文合校). Cult Relics Press, Beijing, p 427
44. Xuehui Fan (1999) Study on private weapons of Han dynasty (Lun lianghan de siren bingqi 论两汉的私人兵器). J Shandong Univ (Philosophy and Social Sciences), 1:52-58

Publisher's Note Springer Nature remains neutral with regard to jurisdictional claims in published maps and institutional affiliations. 